\title{
Pengembangan E-Modul Berbasis Etnomatematika Untuk Meningkatkan Kemampuan Pemecahan Masalah
}

\author{
Rizky Esti Utami, Aryo Andri Nugroho, Ida Dwijayanti, \\ dan Anton Sukarno \\ Pendidikan Matematika, Universitas PGRI Semarang; rizkyesti@gmail.com
}

\begin{abstract}
Dikirim: 31 Agustus 2018 ; Diterima: 27 September 2018; Dipublikasikan: 25 September 2018 Cara sitasi: Utami, R.E., Nugroho, A. A., Dwijayanti, I dan Sukarno, A. 2018. Pengembangan E-Modul Berbasis Etnomatematika Untuk Meningkatkan Kemampuan Pemecahan Masalah. JNPM (Jurnal Nasional Pendidikan Matematika) Vol. 2(2), Hal.268-283.
\end{abstract}

\begin{abstract}
Abstrak. Penelitian ini bertujuan untuk menghasilkan media pembelajaran berlandaskan pada budaya baik itu konten materi maupun penyajiannya. Jenis penelitian yang digunakan adalah penelitian pengembangan 4-D (Four-D) Thiagarajan Semmel dan Semmel. Metode pengumpulan dan analisis data yang digunakan ialah metode dokumentasi, observasi, angket serta tes. Seluruh data dianalisis secara deskriptif. Hasil penelitian pada tahap pendefinisian dan perancangan memunculkan unsur budaya daerah antara lain: tarian tradisional Jawa Tengah, bangunan bernilai budaya dan makanan khas daerah. Kemudian dilakukan tahapan pengembangan yaitu dengan validasi ahli dan uji keterbacaan pada e-modul pembelajaran matematika kelas VII SMP berbasis etnomatematika yang telah teruji valid dengan rata-rata nilai dari validator media yaitu $90 \%$, rata-rata nilai dari validator materi yaitu 93\% dan rata-rata nilai dari validator budaya $88 \%$. Sedangkan hasil uji keterbacaan menunjukkan bahwa bahasa yang digunakan dalam e-model matematika berbasis etnomatematika adalah bahasa yang mudah dipahami dan tidak mengandung makna ganda.
\end{abstract}

Kata Kunci: E-Modul, Etnomatematika, Budaya

\begin{abstract}
This study aims to produce learning media based on culture, both material content and presentation. The type of research used is the 4-D (Four-D) development research of Thiagarajan Semmel and Semmel. Data collection and analysis methods used are documentation, observation, questionnaires and tests. All data were analyzed descriptively. The results of the research at the defining and designing stage gave rise to regional cultural elements including: Central Javanese traditional dance, cultural value building and regional specialties. Then the development stage is carried out by expert validation and readability test on mathematics learning e-module class VII SMP based on ethnomatematics which has been proven valid with an average value of media validator that is $90 \%$, the
\end{abstract}


average value of the material validator is $93 \%$ and flat The value of the cultural validator is $88 \%$. Whereas the readability test results indicate that the language used in e-mathematical e-models based on ethnomatematics is language that is easy to understand and does not contain multiple meanings.

Keywords: E-Module, Ethnatics, Culture

\section{Pendahuluan}

Kurikulum 2013 menuntut siswa untuk menguasai beberapa aspek yang dijadikan penilaian akhir dalam penilaian pengetahuan, penilaian keterampilan, dan penilaian sikap. Penilaian-penialain dalam kurikulum 2013 berorientasi pada berfikir tingkat tinggi atau higher order thingking (HOT). Newman and Wehlage (2011) menyatakan bahwa dengan HOT siswa dapat membedakan ide atau gagasan secara jelas, berargumen dengan baik serta mampu memecahkan masalah. Namun pada kenyataannya dari 100 peserta didik yang dikirim mengikuti lomba tingkat internasional yang diselenggarakan PISA (Program for International Students Assessment), 73 di antara 100 peserta didik yang dikirim berada di bawah level 1 (Sujak, 2005 \& Surya-Dharma, 2009).

Pendidikan dan budaya adalah sesuatu yang tidak bisa dihindari dalam kehidupan sehari-hari, karena budaya merupakan kesatuan yang utuh dan menyeluruh, berlaku dalam suatu masyarakat dan pendidikan merupakan kebutuhan mendasar bagi setiap inidividu dalam masyarakat. Melalui kegiatan studi dokumentasi kurikulum 2013 yang terevisi diperoleh permasalahan, yaitu: pada capaian KI 3 ditetapkan: "memahami pengetahuan (faktual, konseptual, dan prosedural) berdasarkan rasa ingin tahunya tentang ilmu pengetahuan, teknologi, seni, budaya terkait fenomena dan kejadian tampak mata". Salah satu yang dapat menjembatani antara budaya dan pendidikan adalah etnomatematika. Etnomatematika adalah bentuk matematika yang dipengaruhi atau didasarkan budaya. Melalui penerapan etnomatematika dalam pendidikan khususnya pendidikan matematika diharapkan nantinya peserta didik dapat menguasai kemampuan matematika yang ditargetkan tanpa meninggalkan nilai budaya yang dimiliki (Wahyuni, 2013). Dalam kurikulum 2013 terevisi, unsur budaya belum menjadi bagian dari konten yang ditekankan. Hal ini terihat dari bahan ajar yang beredar di pasaran. Di lain pihak, Depdiknas (2008) menyebutkan salah satu tujuan pengembangan bahan ajar ialah 
Menyediakan bahan ajar yang sesuai dengan tuntutan kurikulum dengan mempertimbangkan kebutuhan siswa, yakni bahan ajar yang sesuai dengan karakteristik dan setting atau lingkungan sosial siswa. Disamping itu, pengembangan bahan ajar yang ada selama ini masih bersifat umum, artinya belum mampu memfasilitasi pencapaian kemampuan khusus. Hal ini tidak sejalan dengan pendapat Dick, Carey, dan Carey (2009: 230) yang menyatakan bahwa bahan ajar berisi konten yang perlu dipelajari oleh siswa baik berbentuk cetak atau yang difasilitasi oleh pengajar untuk mencapai tujuan tertentu. Selain konten bahan ajar, format dari bahan ajar merupakan bagian penting dalam pembelajaran karena format merupakan salah satu penentu keberhasilan proses penyampaian pesan dari sumber pesan (pendidik) ke penerima pesan (peserta didik). Media yang baik juga akan mampu memberikan motivasi dan meningkatkan ketrampilan dasar peserta didik (Tinio, 2002). Pembelajaran dengan menggunakan bahan ajar berupa emodul berbasis etnomatematika diharapkan dapat meningkatkan pemecahan masalah sehingga akan menghasilkan prestasi belajar yang baik. Penelitian ini bertujuan mengembangkan e-modul berbasis etnomatematika yang mampu memberikan kontribusi pada kemampuan pemecahan masalah tanpa meninggalkan nilai budaya yang dimiliki.

\section{Metode Penelitian}

Penelitian ini tergolong dalam penelitian pengembangan. Selain E-Modul, keseluruhan perangkat yang dikembangkan dalam penelitian ini meliputi: (1) RPP (Rencana Pelaksanaan Pembelajaran), (2) E-Modul, dan (3) tes pemecahan masalah matematika.

Instrumen penelitian meliputi: (1) lembar validasi RPP, (2) lembar validasi E-Modul (ahli media), (3) lembar validasi E-Modul (ahli materi), (4) lembar validasi E-Modul (ahli budaya), (5) lembar validasi tes pemecahan masalah matematika, (6) lembar pengamatan aktivitas peserta didik yang berkaitan dengan penerapan etnomatematika, dan (7) angket keterbacaan untuk guru dan peserta didik; (8) angket respon peserta didik terhadap perangkat pembelajaran dan proses pembelajaran. 
Variabel dalam penelitian ini : (a) Respon Validator ahli media; (b) Respon Validator ahli materi; (c) Respon Validator ahli budaya; (d) Kemampuan pemecahan masalah matematika, ialah kemampuan peserta didik dalam menyelesaikan persoalan yang diberikan melalui tes tertulis yang memuat indikator pemecahan masalah ; dan (e) Aktivitas dan Repon Peserta didik

Prosedur pengembangan e-modul menggunakan model 4-D (Four D model) dari Thiagarajan (1974: 5 - 9) yang terdiri dari 4 tahapan, yaitu: (1) pendefinisian (define), (2) perancangan (design), (3) pengembangan (develop), (4) tahap penyebaran (desseminate). Pada penelitian ini dibatasi sampai tahap pengembangan (develop).

Metode pengumpulan dan analisis data yang digunakan menggunakan metode: (a) Metode dokumentasi: digunakan untuk memperoleh data awal digunakan untuk mengetahui kondisi bahan ajar yang ada, adanya aplikasi budaya dalam pembelajaran matematika, telaah kurikulum, konten budaya yang relevan dengan materi serta kemampuan pemecahan masalah peserta didik. Data ini dianalisis secara deskriptif; (b) Metode observasi: digunakan untuk memperoleh data tentang kebutuhan calon guru dan metode dosen dalam mengelola pembelajaran. Data ini dianalisis secara deskriptif; dan (c) Metode angket: digunakan untuk memperoleh data tentang pendapat ahli tentang bahan ajar yang dikembangkan serta keterbacaan peserta didik terhadap perangkat. Data ini dianalisis secara deskriptif.

\section{Hasil dan Pembahasan}

Proses pengembangan yang dilakukan mengacu pada model pengembangan 4D yang dikemukakan oleh Thiagarajan (1974: 5 - 9). Prosedur pengembangan e-modul menggunakan model 4-D (Four D model) ini sejatinya terdiri dari 4 tahapan namun dalam penelitian ini tahapan yang dilakukan hanya 3. Adapun tahapan dan seluruh kegiatan dijabarkan seperti berikut.

\section{Tahap Pendefinisian}

Analisis awal-akhir

Kurikulum 2013 terevisi belum menempatkan unsur budaya belum menjadi bagian dari konten yang ditekankan. Hal ini terlihat dari RPP yang beredar di pasaran. Sebagian besar menggunakan konten yang telah disediakan 
pada bahan ajar yang beredar di masyarakat. Contoh konten yang kurang sesuai dengan sebagian besar budaya siswa kelas VII Sekolah Menengah Pertama dapat dilihat pada Gambar 1. Dari gambar terlihat bahwa konten yang digunakan pada salah satu BSE yang beredar di pasaran ialah nilai gizi pada sebuah biskuit pada materi perbandingan. Konten ini terlalu berat untuk disajikan pada peserta didik kelas VII SMP karena konten tersebut jarang ditemui atau diperhatikan peserta didik sehingga peserta didik membutuhkan waktu untuk menyesuaikan dengan skema pengetahuan yang telah dimiliki.

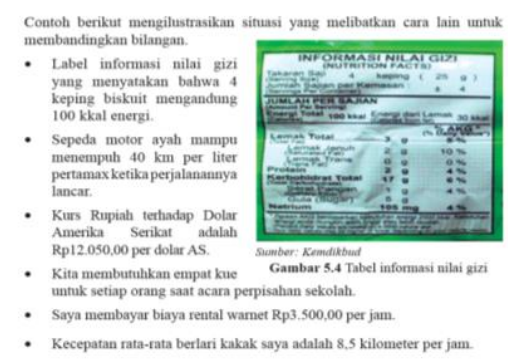

\section{Gambar 1. Konten BSE \\ Sumber: BSE 2013}

\section{Analisis Peserta didik}

Dengan metode dokumentasi dan studi dokumentasi diperoleh hasil analisis peserta didik bahwa peserta didik SMP sekarang sudah mengenal teknologi dengan baik seperti komputer/laptop, handphone. Pengetahuan yang peserta didik miliki sebelumnya kurang mengenal budaya mereka terutama pada masalah matematika dalam kehidupan sehari hari. Hal ini terlihat dari keinginan tujuan tempat wisata yang ingin dikunjungi, tidak ada ketertarikan dengan tempat-tempat sejarah ataupun cagar budaya. Selain itu, pembelajaran yang ada kurang menuntut aktivitas peserta didik sehingga keikutsertaan peserta didik dalam pembelajaran masih kurang serta masih kurangnya penggunaan media pembelajaran pada pelajaran matematika.

\section{Analisis Materi}

Berdasarkan diskusi dengan guru-guru matematika SMP di MGMP, pada kurikulum 2013 terdapat materi yang konsepnya belum secara utuh menyentuh unsur budaya jawa tengah terutama budaya yang dekat dengan kehidupan peserta didik. Materi-materi tersebut antara lain materi perbandingan, aritmetika sosial, garis dan sudut, segiempat dan segitiga, 
penyajian data. Untuk itu, pada penelitian ini bertujuan mengembangkan bahan ajar berbasis etnomatematika.

Analisis Tugas

Analisis tugas dilakukan setelah mengetahui materi yang akan diajarkan sehingga dapat diketahui tugas-tugas yang harus diselesaikan peserta didik selama pembelajaran dilaksanakan.

Spesifikasi tujuan pembelajaran

Berdasarkan analisis materi dan analisis tugas yang telah dilakukan dapat dihasilkan tujuan pembelajaran khusus yang merupakan dasar untuk menyusun tes dan merancang materi pembelajaran. Namun tak jarang, bahan ajar yang dikembangkan oleh guru tidak disesuaikan dengan karakteristik peserta didik maupun lingkungan sosial peserta didik. Sebagaimana buku-buku sekolah elektronik yang banyak beredar dan banyak digunakan oleh para guru, hanya digunakan tanpa adanya penyesuaian konten dengan konten-konten yang sering dijumpai peserta didik dalam kehidupan sehari-hari. Hal ini terlihat dari tema yang digunakan dalam bahan ajar jarang yang berbasis kearifan lokal daerah tempat tinggal siswa.

\section{Tahap Perancangan}

1) Pemilihan Media: Pemilihan media juga mengacu pada pemanfaatan ICT dalam pembelajaran yaitu: (1) dinamis \& alat-alat visual yang memungkinkan dapat dieksplorasi di ruang bersama; dan (2) memberikan variasi selama pembelajaran, perhatian tidak hanya pada guru.

2) Pemilihan format: Bahan ajar disajikan dalam pendekatan scientifik yang melalui kegiatan: mengamati, menanya, mengumpulkan informasi, bernalar dan membuat jejaring atau berbagi. Selain itu, bahan ajar juga menghadirkan budaya dalam penyajian materi matematika.

3) Perancang Awal: Kegiatan ini merupakan perencanaan merancang dan mendasin e-modul berbasis etnomatematika dengan menyesuaikan analisis awal-akhir, analisis peserta didik, analisis materi, analisis tugas dan spesifikasi tujuan pembelajaran.

a) E-modul yang dikembangkan menghadirkan konten-konten budaya dalam penyajian materi. Seperti halnya jumlah penari Gambyong dan Bondan pada konsep perbandingan. 


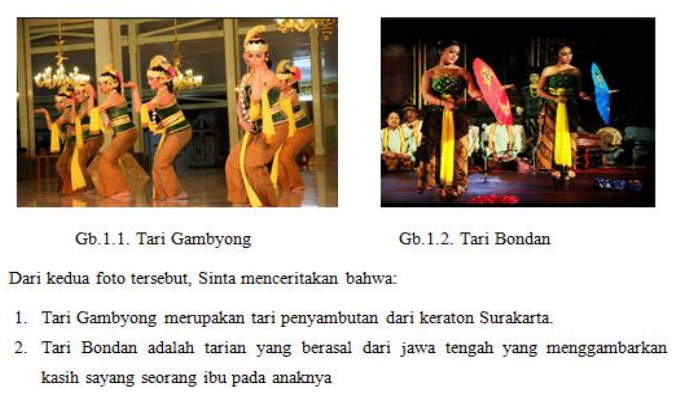

Gambar 2. Jumlah Penari Tarian Tradisional Jawa Tengah

b) Penggunaan peta wisata jawa tengah untuk mengajarkan konsep perbandingan senilai dan skala serta pergeseran.

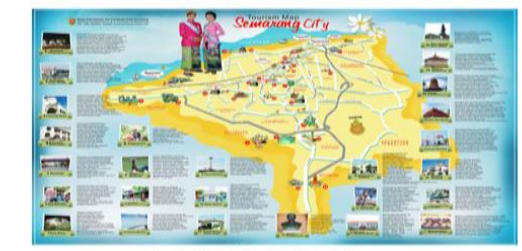

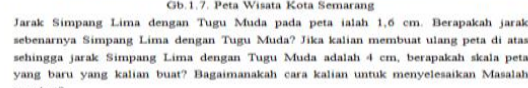

Gambar 3. Peta Wisata Jawa Tengah

c) Penggunaan foto bangunan-bangunan bernilai budaya di jawa tengah sebagai bahan eksplorasi materi perbaningan maupun bangun datar

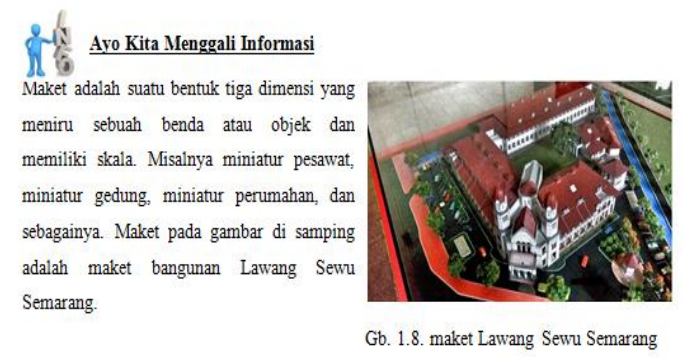

Gambar 4. Bangunan bernilai Budaya di Jawa Tengah

\section{Tahap Pengembangan}

Pada tahap pengembangan menghasilkan draf e-modul berbasis etnomatematika. Kegiatan yang dilakukan pada tahap ini adalah penilaian ahli dan uji keterbacaan. e-modul berbasis etnomatematika yang sudah dirancang divalidasi oleh ahli media, ahli materi dan ahli budaya untuk mendapatkan masukan dan saran untuk merevisi draft 1 menjadi draft II.

Validasi Media Pada E-Modul Berbasis Etnomatematika 
Pada umumnya validator menyatakan e-modul baik dan dapat digunakan dengan sedikit revisi. Validator memberi nilai rata-rata 90\%. Berdasarkan hasil validasi ahli, beberapa revisi yang dilakukan terhadap e-modul dapat dilihat pada Tabel 1.

Tabel 1. Revisi Media Pada E-Modul Berdasarkan Masukan dari Validator Media Sebelum Revisi Media Sesudah Revisi

a) Perpaduan warna kurang proposional

a) Warna sudah disesuaikan dengan kebutuhan

b) Gambar dengan teks beberapa kurang serasi

b) Gambar dan teks sudah disesuaikan

c) Desain cover bisa lebih disederhanakan lagi supaya tidak rame dan maknanya mengena

c) Cover sudah disesuaikan dengan makna dan sudah lebih sederhana

d) Alangkah baiknya jika dimunculkan video

d) Sudah dimunculkan video sebagai unsur budayanya

\section{Validasi Materi Pada E-Modul Berbasis Etnomatematika}

Pada umumnya validator menyatakan materi e-modul sudah baik dan dapat digunakan dengan sedikit revisi. Rata-rata penilaian validator yaitu 93\%. Secara khusus validator memrikan perhatian pada pendekatan yang digunakan dalam penyajian e-modul. Menurut validator kegiatan scientifik yang diusung dalam e-modul perlu dipertegas sehingga tidak tersirat lagi. Peserta didik tidak perlu meraba kembali adanya kegiatan scientifik yang diharapkan dapat hadir dalam proses pembelajaran. Berdasarkan hasil validasi ahli, beberapa revisi yang dilakukan dapat dilihat pada Tabel 2.

Tabel 2. Revisi Materi Pada E-Modul Berdasarkan Masukan dari Validator

\section{Materi Sebelum Revisi}

Materi Sesudah Revisi

a) Ada beberapa teks yang kurang a) Sudah lebih diperjelas teksnya jelas

b) Soal latihan sudah disesuaikan

b) Soal latihan tidak sesuai dengan jumlah kegiatan belajarnya

c) Pembahasan di contoh soal sudah bagus tetapi masih ada yang kurang jelas algoritmanya 


\section{Validasi Budaya Pada E-Modul Berbasis Etnomatematika}

Pada umumnya validator menyatakan budaya yang dimunculkan pada emodul sudah baik dan dapat digunakan dengan sedikit revisi. Rata-rata penilaian validator yaitu $88 \%$. Secara khusus, validator memberikan perhatian pada jenis konten budaya yang dihadirkan dalam e-modul. Validator berpendapat bahwa konten budaya yang dihadirkan masih terpusat pada budaya yang berada di semarang, sehingga validator memberikan saran agar menggali konten budaya yang berada di seluaruh wilayah jawa tengah untuk dieksplor dalam e-modul. Berdasarkan hasil validasi ahli, beberapa revisi yang dilakukan dapat dilihat pada Tabel 3.

Tabel 3. Revisi Budaya Pada E-Modul Berdasarkan Masukan dari Validator

\section{Budaya Sebelum Revisi}

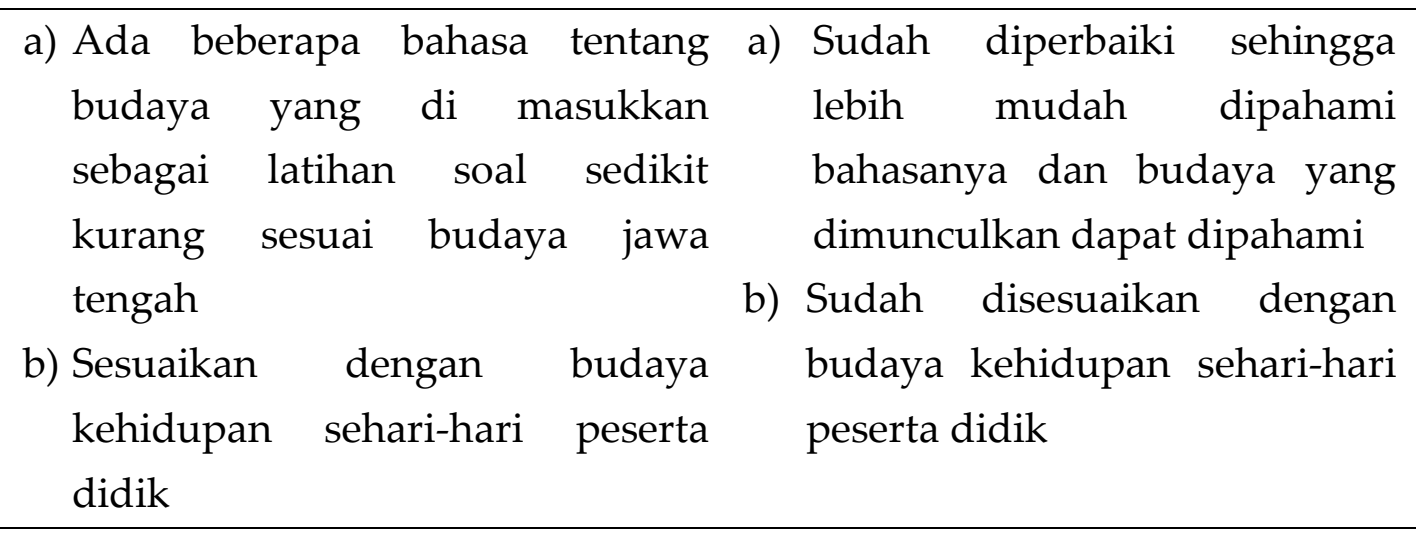

Berdasarkan hasil validasi ahli terhadap e-modul diperoleh hasil validasi emodul berbasis etnomatematika sesuai dengan kriteria yang ditentukan valid. Rata-rata nilai dari validator media yaitu 90\%, rata-rata nilai dari validator materi yaitu 93\% dan rata-rata nilai dari validator budaya $88 \%$. Kegiatan lain yang dilakukan pada tahapan pengemabangan ialah uji keterbacaan dengan hasil keberadaan guru membantu mereka memahami bahasa yang ada dalam perangkat sehingga seluruh kata yang ada dapat mereka pahami maknanya.

Tahap pendefinisian merupakan langkah awal model pengembangan 4D yang dikemukakan oleh Thiagarajan (1974: 5 - 9). Tahapan yang diawali dengan kegiatan analisis Awal-akhir ini dilakukan melalui kegiatan studi dokumentasi kurikulum 2013 yang terevisi diperoleh permasalahan, yaitu 
kurikulum 2013 terevisi belum menjadikan unsur budaya menjadi bagian dari konten yang ditekankan. Tentu saja ini berdampak pada proses pemahaman materi oleh peserta didik, dimana pengetahuan yang dikenali dan dekat dengan peserta didik akan lebih mudah dipahami dan bermakna. Hal ini sesuai dengan teori Ausubel (Herpratriwi, 2016) tentang belajar bermakna yaitu belajar akan lebih bermakna ika materi baru memiliki kesamaan dengan pengetahuan yang dimiliki yang ia dapat melalui pengalaman. Di lain pihak, Depdiknas (2008) menyebutkan salah satu tujuan pengembangan bahan ajar ialah menyediakan bahan ajar yang sesuai dengan tuntutan kurikulum dengan mempertimbangkan kebutuhan siswa, yakni bahan ajar yang sesuai dengan karakteristik dan setting atau lingkungan sosial siswa. Disamping itu, pengembangan bahan ajar yang ada selama ini masih bersifat umum, artinya belum mampu memfasilitasi pencapaian kemampuan khusus. Hal ini tidak sejalan dengan pendapat Dick, Carey, dan Carey (2009: 230) yang menyatakan bahwa bahan ajar berisi konten yang perlu dipelajari oleh peserta didik baik berbentuk cetak atau yang difasilitasi oleh pengajar untuk mencapai tujuan tertentu. Modul sebagai bahan ajar diperlukan oleh peserta didik sebagai panduan atau petunjuk dalam kegiatan pembelajaran sehingga peserta didik sudah mengetahui apa yang akan dipelajari serta dapat mengembangkannya saat pembelajaran dikelas melalui diskusi dengan teman sejawat maupun dengan gurunya (Pratiwi, 208:2017). Materi ajar juga sangat mendukung untuk membangun karakter peserta didik, sesuai dengan pilar karakter yang ditetapkan oleh pemerintah dalam program pendidikan karakter di sekolah (Nugrahani, 484:2017). Oleh karena itu diperlukan sebuah bahan ajar yang dirancang sesuai dengan kehidupan sehari - hari peserta didik dengan mendekatkan budaya daerah, tempat bersejarah dan makanan khas daerah terutama wilayah Jawa Tengah sehingga dengan menyisipkan unsur budaya daerah, peserta didik tetap mengenal budaya daerah, tempat bersejarah dan makanan khas daerah terutama yang berkaitan dengan permasalahan matematika.

Berdasar pada variasi jenis-jenis bahan ajar yang dikemukakan Mulyasa (2006: 96), maka bahan ajar yang akan dikembangkan menggunakan media Elektronik. Hal ini ditujukan agar bahan ajar bisa dimanfaatkan kapanpun dan dimanapun. Selain itu pemilihan media juga mengacu pada pemanfaatan ICT dalam pembelajaran seperti dikemukakan Molvold (2008). 
Format penyusunan mengacu pada standart bahan ajar yang ditetapkan pemerintah dalam Depdiknas (2008) tentang panduan pengembangan bahan ajar telah menyatakan hal-hal yang perlu diperhatikan dalam bahan ajar. Selain itu, bahan ajar juga menghadirkan budaya dalam penyajian materi matematika.

E-modul yang dikembangkan dalam penelitian ini menghadirkan kontenkonten budaya dalam penyajian materi. Seperti halnya jumlah penari Gambyong dan Bondan pada konsep perbandingan. Pendekatan budaya daerah terkait tarian tradisional dapat membuat peserta didik mengenal tarian tradisonal Jawa Tengah sehingga tarian tradisional Jawa Tengah tidak menghilang seiring berjalannya waktu. Penggunaan peta wisata Jawa Tengah untuk mengajarkan konsep perbandingan senilai dan skala serta pergeseran serta penggunaan foto bangunan-bangunan bernilai budaya di jawa tengah sebagai bahan eksplorasi materi perbaningan maupun bangun datar. Pendekatan peta dan foto bangunan bersejarah di Jawa Tengah dapat mengenalkan tempat wisata dan bersejarah di Jawa Tengah bahkan tempat kuliner makanan khas daerah Jawa Tengah. Pada penelitian ini mengembangkan e-modul dengan permasalahan matematika yang akan dirancang pada e-modul menggunakan pendekatan budaya daerah yang dinamakan sebagai etnomatematika dan disesuaikan dengan kurikulum terbaru yaitu kurikulum 2013 terevisi.

Hasil penelitian menunjukkan rata-rata nilai dari validator media yaitu $90 \%$, rata-rata nilai dari validator materi yaitu 93\% dan rata-rata nilai dari validator budaya $88 \%$. Berikut akan dibahas hasil validasi terhadap E-Modul berbasis Etnomatematika. E-Modul yang dikembangkan mengacu pada fungsi ICT yang dikemukakan Mosvold (2008) sehingga penilaian dari ahlipun merepresentasikan fungsi yaitu sebesar 90\%. Materi pembelajaran yang dirancang sesuai dengan kurikulum 2013 terevisi dan Materi yang digunakan dalam e-modul ini antara lain : (1) materi perbandingan dengan memasukkan unsur budaya jawa tengah yaitu (a) harga topi blangkon, (b) jumlah penari tarian yang ada di jawa tengah seperti tari gambyong berjumlah 3 penari, tari bedaya ketawang berjumlah 9 penari, tari serimpi berjumlah 4 penari, tari kuda lumping berjumlah 8 penari, tari bondan payung berjumlah 2 penari, (c) membangun rumah adat; (2) materi aritmetika sosial dengan memasukkan unsur budaya jawa tengah yaitu (a) jual beli batik yang ada di daerah jawa tengah seperti batik pekalongan, batik 
solo, batik semarangan, (b) jual beli makanan khas daerah jawa tengah seperti nasi lengko, nasi grombyang, nasi megono, nasi gandul, telur asin, mendoan, sate blengong; (3) materi garis dan sudut dengan memasukkan unsur budaya jawa tengah yaitu mengeksplor tempat wisata wilayah jawa tengah pada peta seperti menarik garis dari lawang sewu ke kota lama semarang, menarik garis dari museum ronggowarsito ke gereja blenduk, menarik garis dari gereja blenduk ke lawang sewu diteruskan ke sampokong, menari garis dari pagodha semarang ke sampokong diteruskan ke lawang sewu; (4) materi segiempat dan segitiga dengan memasukkan unsur budaya jawa tengah seperti bentuk bangunan rumah joglo, rumah limasan, masjid agung jawa tengah, gereja blenduk; (5) materi penyajian data dengan memasukkan unsur budaya jawa tengah yaitu jumlah bangunan bersejarah di jawa tengah, jumlah tempat rekreasi di jawa tengah. Materi dirancang dengan latihannya berupa soal pemecahan masalah yang memenuhi unsur budaya jawa tengah yang nantinya peserta didik diminta mengerjakan secara uraian di kertas masing-masing.

Unsur budaya merupakan salah satu hal yang ditekankan Kurikulum 2013 pada capaian KI 3 yaitu: "memahami pengetahuan (faktual, konseptual, dan prosedural) berdasarkan rasa ingin tahunya tentang ilmu pengetahuan, teknologi, seni, budaya terkait fenomena dan kejadian tampak mata". Unsur budaya yang diangkat dalam e-Modul ialah budaya jawa tengah, hal ini mengacu pada sasaran pengguna produk ialah siswa Sekolah Menengah Pertama di wilayah Jawa Tengah. Hal ini sejalan dengan pandangan Shirley (2001), yang berpandangan bahwa sekarang ini bidang etnomathematika, yaitu matematika yang timbul dan berkembang dalam masyarakat dan sesuai dengan kebudayaan setempat, merupakan pusat proses pembelajaran dan metode pengajaran.

Penelitian ini menempatkan Budaya pada posisi penting dalam pembelajaran matematika. Hal ini mengacu pada sejumlah penelitian yang telah dilakukan sebelumnya tentang peran budaya dalam pendidikan yaitu penelitian yang dilakukan Sukarno, Dwijayanti \& Harun (2014) yang mengangkat judul penelian pemecahan masalah penyimpangan budaya melalui pendidikan dengan perencanaan pembelajaran berorientasi socio humanism berbantu website serta Dwijayanti (2014) yang mengangkat efektifitas kelas humanistik dalam mengembangkan karakter siswa. Tahapan 
Validasi ahli dalam penelitian ini mendukung penelitian-penelitian sebelumnya yang juga menggunakan cara validasi terhadap ahli untuk melihat validitas isi produk yang dikembangkan. Adapun penelitian penelitian tersebut antara lain: Dwijayanti (2011) dalam upaya pengembangan perangkat pembelajaran matematika humanistik berbasis konstruktivis; Nugroho (2011) mengembangan perangkat pembelajaran matematika berbasis SMART; Nugroho (2014) yang mengembangkan berbantu Edmodo; Nugroho (2015) yang mengembangkan media pembelajaran berbasis mobile learning; Dwijayanti (2016) yang mengembangkan perangkat pembelajaran berbasis pendidikan multikultural; dan Dwijayanti \& Rasiman (2017) yang mengembangkan bahan ajar berbasis digytal storytelling.

\section{Simpulan dan Saran}

Berdasarkan proses pengembangan perangkat pembelajaran dengan menggunakan modifikasi pengembangan perangkat model 4-D four $D$ models) yang telah dilakukan, maka dapat disimpulkan bahwa proses pengembangan E-Modul Matematika berbasis dimulai dari tahap pendefinisian dimana ditemukan data bahwa sebagian besar bahan ajar yang beredar di masyarakat menggunakan konten yang asing bagi peserta didik yang menggunakan, sehingga diperlukan usaha lebih agar siswa mampu melakukan penyesuain dengan skema pengetahuan yang telah dimiliki sehingga disusun Draf 1 bahan ajar berbasis etnomatematika yang menggunakan konten-konten budaya lokal di sekitar peserta didik. Unsur budaya yang dihadirkan dalam e-modul antara lain: jumlah penari tarian tradisional jawa tengah pada materi perbandingan, eksplorasi bangunan bernilai budaya seperti Lawang Sewu, Masjid Agung Jawa Tengah, klenteng Sam Poo Kong, dll pada materi perbandingan, segitiga dan segiempat, serta materi statistika dan peluang. Serta eksplorasi makanan khas daerah seperti sate blengong, tempe komul, kue moci, bandeng presto, dll pada materi persamaan dan pertidak samaan linier satu variabel, aritmatika sosial serta materi statistika dan peluang. Kemudian dilakukan tahapan pengembangan yaitu dengan validasi ahli untuk merevisi draf 1 menjadi draf 2 serta uji keterbacaan untuk merevisi draf 2 menjadi draf 3 yaitu e-modul pembelajaran matematika kelas VII SMP berbasis etnomatematika yang telah teruji valid dengan rata-rata nilai dari validator media yaitu $90 \%$, rata-rata 
nilai dari validator materi yaitu $93 \%$ dan rata-rata nilai dari validator budaya $88 \%$. Sedangkan hasil uji keterbacaan menunjukkan bahwa bahasa yang digunakan dalam e-model matematika berbasis etnomatematik adalah bahasa yang mudah dipahami dan tidak mengandung makna ganda.

\section{Datar Pustaka}

Arthur L. B. 2008. Problem Solving. U.S.A: Wikimedia Foundation, Inc. Tersedia: http://en.wikipedia.org/wiki/Problem Solving

Barton, B. (1996). Making Sense of Ethnomathematics: Ethnomathematics is Making Sense. Educational Studies in Mathematics, 31(1-2), 201-33.

Bell, F. H. 1978. Teaching and Learning Mathematics (In Secondary School). Iowa: Wm. C. Brown Company Publisher.

Buchory, M. S., Rahmawati, S., dan Wardani, S. 2017. The Development of A Learning Media for Visualizing The Pancasila Values Based on Information and Communication Technology. Cakrawala Pendidikan No. 3

Cahyaningrum, N., \& Sukestiyarno, Y. L. 2017. Pembelajaran React Berbantuan Modul Etnomatematika Mengembangkan Karakter Cinta Budaya Lokal Dan Meningkatkan Kemampuan Pemecahan Masalah. Unnes Journal of Mathematics Education Research. Vol 5(1): 50-59.

Carson, J. 2007. A Problem With Problem Solving: Teaching Thingking Without Teaching Knowledge. The Mathematics Educator Journal, 17 (2), 7-14.

Clark, C., Guskey, T., \& Benninga, J. 1983. The effectiveness of mastery learning strategies in undergraduate education courses. Journal of Educational Research, 76(4): 210-214.

Depdiknas. 2008. Panduan Pengembangan Bahan Ajar. Jakarta: Direktorat Jendral Managemen Pendidikan Dasar dan Menengah.

DePorter, Bobbi \& Hernacki, Mike. (2000). Quantum Learning : Membiasakan Belajar Nyaman dan Menyenangkan. Penerjemah : Alwiyah Abdurrahman. Bandung : Sari Meutia

Dindyal, J. 2005. Emphasis on Problem Solving in Mathematics Textbooks from Two Different Reform Movements. Johor Baru Malaysia: The Mathematics Education into the 21st Century Project Universiti Teknologi Malaysia, Reform, Revolution and Paradigm Shifts in Mathematics Education, Johor Baru, Malaysia, Nov 25th - Dec 1st 2005.

Dwijayanti, I. 2016. Pengembangan Perangkat Pembelajaran Matematika Berbasis Pendidikan Multikultural Menggunakan Socio Humanism. JIPMat. Vol 1(1): 
Goldstein F. C., \& Levin H. S. 1987. Disorders of reasoning and problemsolving ability. Dalam M. Meier, A. Benton, \& L. Diller (Ed.), Neuropsychological rehabilitation. London: Taylor \& Francis Group Halat, E. 2006. Sex-Related Differences In The Acquisition Of The Van Hiele Levels And Motivation In Learning Geometry. Asia Pacific Education Review Copyright 2006 by Education Research Institute. 7(2): 173-183.

Herpratiwi. 2016. Teori Belajar dan Pembelajaran. Yogyakarta: Media Akademi Matlin, M. W. 2003. Cognition. Fifth Edition. Rosewood Drive, Danvers, MA: John Wiley \& Sons, Inc.

Mosvold dan Reidar. 2008. ICME. Norway: Mathematics Education at University of Stavanger. [online] tersedia di http://mathedresearch.blogspot.com/2008/07/icme-11-day-2.html

Newman, F. M., Wehlage, G. 1993. Five standards of authentic instruction. Educational Leadership. Vol 50 (7): 8-12.

Nugrahani, F. 2017. The Development of Film-Based Literary Materials Which Support Character Education. Cakrawala Pendidikan No. 3

Nugroho, A. A \& Dwijayanti, I. 2016. Proses Berpikir Mahasiswa ditinjau dari Kemampuan Metakognitif Awala dalam Pemecahan Masalah Matematis. Jurnal Penelitian dan Pembelajaran Matematika. Vol 9 (1): 2532.

Nugroho, A. A. 2011. Pengembangan Perangkat Pembelajaran Matematika Berbasis SMART Dengan Strategi TAI Pada Materi segitiga Kelas VII. Aksioma. Vol 2 (2).

Nugroho, A. A. 2014. Pengembangan Media Pembelajaran Matematika Dengan Strategi Project Based Learning Berbantuan Edmodo Pada Mata Kuliah Statistik Dasar. Mathematics And Sciences Forum 2014

Nugroho, A. A \& Purwati, H. 2015. Pengembangan Media Pembelajaran Matematika Berbasis Mobile Learning Dengan Pendekatan Scientific. Euclid Vol 2(1)

Polya, G. 1973. How to Solve it. New Jersey: Princeton University Press.

Pratiwi P. H., Hidayah, N. dan Martiana, A. 2017. Pengembangan Modul Mata Kuliah Penilaian Pembelajaran Sosiologi Berorientasi HOTS. Cakrawala Pendidikan No. 2

Purwati, H \& Nugroho, A. 2017. Analisis Kemampuan Komunikasi Matematis Mahasiswa Dalam Menyelesaikan Masalah Pada Mata Kuliah Program Linear. Jurnal Ilmiah Pendidikan Matematika. Vol 1(2): $127-134$.

Rosa, M. \& Orey, D. C. (2011). Ethnomathematics: the cultural aspects of mathematics. Revista Latinoamericana de Etnomatemática, 4(2). 32-54

Saad, N. S. \& Ghani, A. S. 2008. Teaching Mathematics in Secondary School:Theories and Practices. Perak: Universiti Pendidikan Sultan Idris. 
Samsudi. 2009. Desain Penelitian Pendidikan. Semarang: Unnes Pres.

Santoso, S. 2003. Mengatasi Berbagai Masalah Statistik dengan SPSS Versi 11,5. Jakarta: PT. Gramedia.

Shirley, L. 1995. Using Ethnomathematics to find Multicultural Mathematical Connection: NCTM.

Sternberg, R.J. \& Ben-Zeev, T. 1996. The Nature of Mathematical Thinking. Mahwah, NJ: Lawrence Erlbaum Associates,Inc.

Suherman, E. dkk. (2003). Common Textbook: Strategi Pembelajaran Matematika Kontemporer. Bandung: JICA - Universitas Pendidikan Indonesia (UPI).

Sujak. 2005. Wacana kebijakan Sertifikasi Tenaga Kependidikan, Makalah Disampaikan dalam rangka Dies Natalis Universitas Negeri Semarang ke-40.

Sumarmo, U. 2000. Pengembangan Model Pembelajaran Matematika untuk Meningkatkan Kemampuan Intelektual Tingkat Tinggi Siswa Sekolah Dasar. Laporan Hibah Bersaing. Bandung: FPMIPA IKIP Bandung.

Suryadharma. 2009. Arah Kebijakan Peningkatan Mutu Pendidik Tenaga Kependidikan, Makalah disampaikan pada Seminar Nasional dalam rangka Dies Natalis ke-44 Universitas Negeri Semarang.

Sukarno, A., Dwijayanti, I., dan Harun, L. 2014. Pemecahan Masalah Penyimpangan Budaya Melalui Pendidikan Dengan Perencanaan Pembelajaran Berorientasi Socio Humanism Berbantu Website. Aksioma. Vol 5(1): $64-75$

Thiagarajan, S. 1974. Instructional Development for Teacher of Exceptional Children. Bloomington: Indiana University. [online] tersedia di www.eric.ed.gov/ERICWebPortal/recordDetail?accno.

Tinio, V. L. ICT in Education. [online] tersedia di www.apdip.net/publications/iespprimers/eprimer-edu.pdf

Wahyuni, A., Tias, A. A. W dan Sani, B. 2013. Peran Etnomatematika dalam Membangun Karakter Bangsa. Prosiding Seminar Nasional Penguatan Peran Matematika dan Pendidikan Matematika Untuk Indonesia yang Lebih Baik. Yogyakarta: UNY Press 